\title{
Assessment for learning, online tasks, and the new
}

\section{Assessment Resource Banks}

\section{CHRIS JOYCE AND JONATHAN FISHER}

The main purpose for assessment should always be to improve learning (Ministry of Education, 2007). The New Zealand Curriculum (NZC) acknowledges that evidence for assessment for learning is often gathered informally, and "analysis and interpretation, and use of information often take place in the mind of the teacher" (p. 39). At the same time an increasing body of research suggests that assessment for learning isn't easy for teachers (see, for example, Mansell, James, and the Assessment Reform Group (2009)). In this short news article we discuss the changing face of a long-standing resource that helps teachers to use assessment data to improve learning.

Historical focus of the Assessment Resource Banks

The Assessment Resource Banks (ARBs) have been a fixture on the New Zealand assessment landscape since the mid I990s. The innovative decision to deliver downloadable pencil and paper assessment tasks to teachers via the internet initially presented a challenge to many schools. Since then, schools have embraced the internet as communication and information delivery has marched steadily onwards.

How we view assessment has also changed since the mid I990s. The ARBs started off as a bank of discrete questions intended to be used for summative assessment. What was innovative was that teachers could select questions from the appropriate curriculum resource bank and create their own "tests" for students. Gradually, though, as the use of assessment data for improving learning gained traction in schools, the focus of the ARBs changed to providing resources that promote formative assessment (these days often referred to as assessment for learning).

Assessment for learning can be described as the day-to-day information obtained from the immediacy of classroom activities that allows teachers to manage the learning process as it unfolds (Stiggins, 2008). The task itself is important; it should be relevant to a learning goal and give students opportunities to show what they can do with what they know. What makes 
the assessment formative is not the resource itself, but what happens during and after task completion. In other words, it is how the resource is used that determines its value for learning. The important advance for the ARB resources at this stage was to extend the teachers' pages to provide support for teachers to analyse the data from the student responses and to decide what to do next to advance learning.

\section{The new interactive face of the ARBs}

The next iteration for the ARBs is for students to be able to complete the tasks online. Since 20I3, at the New Zealand Council for Educational Research (NZCER) we have been very busy designing a new website to enable this, and to allow for storage of individual and class data. Our resource developers have also been busy designing tasks that are enhanced by the immediate feedback possibilities, use stimulus material available online, support students to reflect on their own learning either independently or by peer assessment, and encourage sharing and knowledge building.

To guide resource design, we developed a set of principles. This was based on research about the necessary elements for effective assessment for learning as well as some considerations for learners in New Zealand-not an exhaustive list, but a starting place. The principles were:

- resources should include support for teachers and students to use them formatively

- tasks should include opportunities for teacher-student or student-student interactions, or a combination of both

- students and teachers should know what high-quality work looks like

- assessment used for formative purposes should enable every student, including those with special education needs, to show what they know and can do

- resources should support teachers to effectively scaffold Māori and Pasifika students' learning in culturally responsive ways.

Interactive assessment tasks do present a different set of challenges from pencil and paper assessment. One of the challenges, for both resource and website developers, has been the desire to stay true to good assessment for learning practices. One area we have thought about is feedback. While resources that are auto-marked have the advantage of providing immediate feedback to students, we also think it important to enhance student-teacher or student-student dialogue, also identified as a crucial aspect of assessment for learning (Black and Wiliam, 2009). Therefore some tasks are designed to use digital technologies that enable sharing and reflection. Also, in some resources we have added examples of how teachers have used the task as a "thinking together" exercise.
Another consideration for new resources has been how to address the future focus principle of $N Z C$. If we want our students to be actively involved citizens both now and in the future, the interest is on students' thinking processes, being able to use their understandings, and working with others to share their ideas and build new knowledge. This is a challenge for assessment because these kinds of capabilities are not necessarily associated with right or wrong answers. For this reason, not all resources are auto-marked, and instead support is given for looking for strategies and thinking that the student is using. Interactions between teachers and students, or between students, are encouraged as students explain their answers.

Yet another consideration for task design has been how to involve students in their assessment and support them to make decisions about their own learning. This has become increasingly recognised as an important aspect of assessment for learning. Reflective questions are built into some tasks to support students to think about their learning. The online environment itself opens up new possibilities for students to be involved in decision making about tasks they complete, judging the quality of their own responses, and next actions to take.

\section{What does the design of the new ARB website offer teachers and students?}

Designing a new website has provided an opportunity to update the look and efficiency of the website. The major changes are related to online assessments and the storing of data. Other things have not changed, although the execution may be different. Table I briefly describes some of the main features of the new website.

Not all tasks are enhanced by interactive technologies, and, as in the initial iteration of the ARBs, some schools are less ready for this step than others. Some teachers will prefer to use print-based resources, so the ARBs will continue to provide teachers with a selection of both pencil and paper and interactive online tasks. Some of the existing resources have been updated so that both options are available. Currently these tend to be resources that lend themselves to auto-marking.

There is still a lot of work to do to allow the website to reach its potential to support assessment for learning. We encourage you to explore the website, try out some tasks (and be innovative about how you use them), and, in the interests of our learning and future improvements, provide us with some timely feedback.

The new ARBs can be accessed from http://live.arb. nzcer.org.nz 
TABLE 1. FEATURES OF THE NEW ASSESSMENT RESOURCE BANKS

\begin{tabular}{|c|c|}
\hline What hasn't changed & What's new \\
\hline $\begin{array}{l}\text { The resources are } \\
\text { specifically designed for } \\
\text { the purpose of assessment } \\
\text { for learning. } \\
\text { The resource developers } \\
\text { have expertise in } \\
\text { assessment as well as the } \\
\text { mathematics, science and/ } \\
\text { or English learning areas. } \\
\text { All tasks are trialled by } \\
\text { New Zealand students, } \\
\text { although, because the } \\
\text { resources are online, the } \\
\text { trialling processes have } \\
\text { changed. } \\
\text { Teacher notes continue } \\
\text { to be provided to support } \\
\text { teachers to use the } \\
\text { assessment data to inform } \\
\text { their teaching. } \\
\text { The old tasks will still be } \\
\text { available, although they } \\
\text { will follow the new format. } \\
\text { (These are gradually } \\
\text { being added as they are } \\
\text { checked.) They will still } \\
\text { be able to be printed } \\
\text { off as pencil and paper } \\
\text { resources. }\end{array}$ & 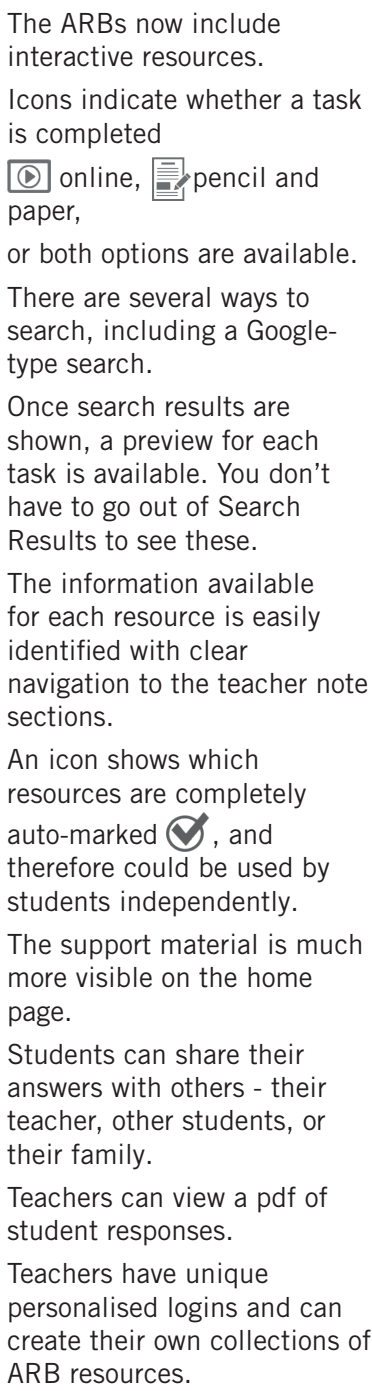 \\
\hline
\end{tabular}

\section{References}

Black, P. and Wiliam, D. (2009). Developing the theory of formative assessment. Educational Assessment, Evaluation, and Accountability, 2I(I), 5-3I.

Mansell, W., James, M. \& the Assessment Reform Group (2009). Assessment in schools. Fit for purpose? A Commentary by the Teaching and Learning Research Programme. London: Economic and Social Research Council, Teaching and Learning Research Programme.

Ministry of Education (2007). The New Zealand curriculum. Wellington: Learning Media.

Stiggins, R. (2008, September). Assessment FOR Learning, the Achievement Gap, and Truly Effective Schools. Presentation to The Educational Testing Service and College Board Conference, Washington, DC. Retrieved from Educational Testing Service, Assessment Training Institute: http://www. ets.org/Media/Conferences_and_Events/pdf/stiggins.pdf.

Chris Joyce is a researcher/resource developer at the New Zealand Council for Educational Research. Until recently she led the Assessment Resource Banks team. She currently designs resources for the science bank.

Email: chris.joyce@nzcer.org.nz

Jonathan Fisher is the manager of the Assessment Resource Banks at the New Zealand Council for Educational Research. He has specific interests in ICT, mathematics education, and assessment.

Email: jonathan.fisher@nzcer.org.nz 